\title{
The Effect of Sikkomodo (Combination of Music, Humor, and Prayer) Formulation Toward Blood Pressure of Hypertension Patient on The Elderly Group in Banyumas Regency
}

\author{
S Awaludin ${ }^{1}$, ASumeru ${ }^{1}$, G N Alivian ${ }^{1}$, D Novitasari $^{2}$ \\ ${ }^{1}$ Health Science Faculty. Jenderal Soedirman University \\ ${ }^{2}$ Faculty of Health Sciences, Harapan Bangsa University
}

\begin{abstract}
Uncontrolled hypertension can lead to heart disease, kidney disease, and stroke. Hence, it needs therapy. There are complementary therapies that can reduce high blood pressure. Music provides a relaxing effect so that blood vessel dilates and blood pressure drops. Humor therapy can provide a relaxation response and decrease blood pressure. Prayer therapy has a positive effect on body physiology that can lower blood pressure. The purpose of this study was to identify the effect of combination of music, humor, and prayertherapy on blood pressure. This study used true experiment pre and post control group design. The number of samples in this study were 131 respondents with primary hypertension on the elderly in Banyumas Regency. The sampling technique used was simple random sampling. Wilcoxon was used to test the difference of blood pressure before and after the intervention in one group, while the difference test among groups employed Mann Whitney test. The result indicated that respondent's hypertension is categorized into moderate. There is difference on the mean of blood pressure before and after SIKKOMODO therapy and combination of music, humor, and humor therapy. There is a significant difference in term of systolicblood pressure betweentreatment and control group, and there is no difference on the systolic blood pressure between the two groups.
\end{abstract}

\section{Introduction}

An individual's health is a physical, mental, and social condition that is not only free from problems of illness and weakness, but also free from all problems ${ }^{[1]}$. A health problem that mostly occurs in the society and is not recognized by the patient is 
hypertension or high blood pressure ${ }^{[2]}$. Theoccurrence of hypertension in Indonesia is quite high. The result of Basic Health Research (Riskesdas) in 2013 showed that most of hypertension cases in the community had not been diagnosed. The prevalence of hypertension in Indonesia is $26.5 \%$, in which only $9.5 \%$ of the population realized having hypertension and only $0.1 \%$ of them who took hypertension medication at the age of 18 and over. This incidence increases as thepeople grow older. The result of the study from Awaludin,et.al (2016) indicated that the incidence of hypertension on the elderly in RW 01 Mersivillage Purwokerto was more than $90 \%$.

Hypertension is a cardiovascular disorder characterized by blood pressure of more than $140 / 90 \mathrm{mmHg}^{[3]}$. High blood pressure is one of the most influential risk factors for the incidence of heart disease and blood vessel disease. Hypertension often shows no symptoms, so it is just realized if it has caused organ impairment such as impaired heart function or its capillary. The majority of people with hypertension find that they have hypertension accidentally such as at the moment of their medical check- up orwhen it comes with other complaints. A person with hypertension in the blood vessels experiences a narrowing or atherosclerosis. With this narrowing, it takes a great pressure to supply blood throughout the body. In addition, it also requires a fast heartbeat. If it lasts a long time, the patient will experience headache, weakness, and discomfort, and can even lead to a decrease in consciousness and cause death $^{[1]}$.

A few of the complementary therapies for lowering blood pressure are music therapy, humor therapy, and prayer therapy ${ }^{[4]}$. Geer (2009) defines music therapy as the use of music to get relaxed, accelerate healing, improve mental function, and create a sense of welfare. Music can affect several physiological functions such as respiration, heart rate, and blood pressure. It stimulates the release of endorphins. Humor therapy is an action to stimulate someone to laugh. It can promote the release of endogenous opiates called endorphins. The benefit of endorphins is to make relaxation which has an impact on the dilation of blood vessels and as a result it can decrease blood pressure. With the relaxed situation, it will also make the heart rate normal. Humor therapy is done using several ways, for example watching funny movies, listening to comedians, looking at funny cartoons, comics and caricatures, and reading a collection of funny storie ${ }^{[5]}$. While prayer therapy which is preceded by $d h i k r$ is a therapy carried out by persuading, conveying the requests utterances, and asking for His protection sincerely ${ }^{[6]}$.Prayer can influence a positive emotional response that will flow to the body and is accepted by the brainstem. After being formatted by the brain language, prayer is transmitted to one part of the cerebrums, thalamus, then the thalamus transmits the hippocampal impulse (a vital center of memory which coordinates everything that is absorbed by the senses) to secrete Gama Amino Batiric Acid (GABA). GABA serves as a controller of emotionalresponse and blockasetylcholine, serotonin, and other neurotransmitters that produce cortisol secretion which leads tohomeostasis process and cause relaxation. As a result, blood pressure can decrease ${ }^{[7]}$.

The three therapies are combined into one therapy formula called SIKKOMODO (musik kombinasi humor dan $\underline{\text { doa }}$ ), a combination of music, humor, and prayer therapy. This therapy formulawill work together to speed up blood pressure reduction. This formula is expected to be an invention to reduce high blood pressure 
non-pharmacologically. The purpose of this study was to find out the effect of SIKKOMODO therapy toward blood pressure to hypertension patients on the elderly group in Banyumas Regency.

\section{Research Methods}

This study used true experiment pre and post control group design. It observed two times, before and after the treatment. The researcher divided the respondents into two groups, one treated using SIKKOMODO therapy as the experimental group and another one given only humor- music combination therapy as the control group. The population were all the inhabitants of Mersi, Ledug, Arcawinangun, and Sumbang villages who had hypertension. The sample of this study was 120 respondents consisting of 60 patients for experimental group (A) and 60 patients for control group (B). The sampling technique used was simple random sampling. The sample in this study was the subjects who met the inclusion criteria. The inclusion criteria were the respondents with the following conditions: willing to be observed, suffering from primary hypertension, having age range 45 - 75 years old, having composmentis. Exclusion criterion in this study was patient having mental disorders. Blood pressure measurement was carried out by using OMRON digital sphygmomanometer that was calibrated. The measurement result was recorded in the observation sheet. Blood pressure measurement in the experimental and control group was assessed twice, before the therapy and right after the therapy. The respondents in group A were given SIKKOMODO therapy by having them listen to instrumental music for 5 minutes, watch a humor therapy video for 10 minutes, and finally have prayer therapy for 5 minutes. Group B respondents only listened to instrumental music for 5 minutes, watched a humor therapy video for 10 minutes, and had no prayer therapy.

Kolmogorov Smirnov test result showed that $\mathrm{p}$ value of systolic pressure from pre group A was 0.059 and the one from pre group B was 0.110 . The p value of systolic pressure from post group B was 0.310 and $p$ value of diastolic pressure from post group B was 0.378; those data had normal distribution. Apart from them, the data was not normally distributed. The difference test between two means of equal groups, diastolic pressure pre and post treatment, in the control group employed parametric test (dependent $\mathrm{t}$ test).

The others used a difference test between two means of equivalent groups with non-parametric test (Wilcoxon). Difference test of different group for systolic blood pressure used parametric test (independent $t$ test). Others used difference test between two means of different group with non- parametric test (Mann Withney).

\section{Result}

1. Blood Pressure Description of Pre- SIKKOMO Therapy

Table 1. Mean Description of Respondent's Blood Pressure of Pre SIKKOMODO Therapy

\begin{tabular}{lll}
\hline Variable & $\begin{array}{c}\text { Treatment Group Mean } \pm \\
\text { SD }\end{array}$ & $\begin{array}{c}\text { Control Group } \\
\text { Mean } \pm \text { SD }\end{array}$ \\
\hline Systolic blood pressure & $170.84 \pm 15,09$ & $173.89 \pm 17.61$
\end{tabular}


$(\mathrm{mmHg})$

Diastolic blood pressure

$98.34 \pm 8,37$

$96.39 \pm 5.81$

$(\mathrm{mmHg})$

Table 1 indicates that the mean of blood pressureis categorized into moderate hypertension (systolic blood pressure is $160-179 \mathrm{mmHg}$ ) in the two groups.

2. Blood Pressure Description of Post-SIKKOMODO Therapy

Table 2. Mean Description of Respondent's Blood Pressure of Post SIKKOMODO Therapy

\begin{tabular}{lcc}
\hline Variable & $\begin{array}{c}\text { Treatment Group Mean } \\
\pm \mathrm{SD}\end{array}$ & $\begin{array}{c}\text { Control Group } \\
\text { Mean } \pm \text { SD }\end{array}$ \\
\hline $\begin{array}{l}\text { Systolic blood pressure } \\
(\mathrm{mmHg})\end{array}$ & $153.01 \pm 16.41$ & $169.40 \pm 17.55$ \\
$\begin{array}{l}\text { Diastolic blood pressure } \\
(\mathrm{mmHg})\end{array}$ & $96.93 \pm 15.38$ & $96.52 \pm 7.16$ \\
\hline
\end{tabular}

Table 2 shows that in the treatment group the mean of blood pressure is classified into mild hypertension (systolic blood pressure is $140-159 \mathrm{mmHg}$ )and in the control group the mean of blood pressure belongs to moderate hypertension category (systolic blood pressure is $160-179 \mathrm{mmHg}$ ).

3. The Difference Test Result of Blood Pressure between Pre- and Post in the Treatment and Control Group

Table 3. The Difference Test Result of Blood Pressure Between Pre- and Post Treatment

Variable

$$
p \text { value Treatment } \quad \text { value Control }
$$

\begin{tabular}{lcc}
\hline Systolic blood pressure & $0.000^{\mathrm{a}}(\mathrm{Z}:-6.96)$ & $0,000^{\mathrm{b}}$ \\
Diastolic blood pressure & $0.000^{\mathrm{a}}(\mathrm{Z}:-4.77)$ & $0,016^{\mathrm{a}}(\mathrm{Z}:-2.41)$ \\
\hline
\end{tabular}

$\mathrm{a}=$ non- parametric test, $\mathrm{b}=$ parametric test

Table 3 shows that the result of test difference of blood pressure in the treatment and control group is significantly different $(\mathrm{p}<0,05)$. The blood pressure of systolic and diastolic in the control group indicates a significant difference, but $\mathrm{Z}$ value is negative. It means blood pressure in the control group significantly.

4. The Effect of SIKKOMODO Therapy on the Respondent's Blood Pressure between Groups

Table 4.The Effect of SIKKOMODO Therapy on the Respondent's Blood Pressure between Groups

\begin{tabular}{lcc}
\hline Variable & $\begin{array}{l}\text { Homogeneity } \\
\text { Test }\end{array}$ & $p$ value \\
\hline Systolic blood pressure & $0.285^{*}$ & 0.000 \\
Diastolic blood pressure & $0.220^{*}$ & $0.486^{*}$ \\
\hline
\end{tabular}

*= not significantly different

Table 4 shows that the data of blood pressure pre- and post in the treatment and control group is not significantly different or homogenous, hence the difference test 
from the data post between groups can be done. The systolic blood pressure in the treatment and control group is significantly different $(\mathrm{p}<0.05)$, while diastolic pressure on the two groups is not significantly different $(p>0.05)$.

\section{Discussion}

Table 1 shows that blood pressure in the treatment and control groups is within moderate hypertension category (systolic blood pressure 160-179 $\mathrm{mmHg}$ ). Table 2 shows that the result of difference test on systolic and diastolic blood pressure before and after treatment in the treatment group indicates significant difference $(p=0.000)$, while in the control group it also shows significant difference but the $\mathrm{Z}$ value is negative, which means that blood pressure in the control group increases significantly. As a matter of fact, what is expected is a decline.

Music therapy can influence several physiological functions such as respiration, heart rate, and blood pressure ${ }^{[8]}$. Slendro gamelan music can decrease blood pressure significantly on hypertension patients. Instrumental music can reduce stress levels on patients with ventilators ${ }^{[9]}$. Decreased stress is followed by vagal outflow and decreased activity of the sympathetic nervous system ${ }^{[10]}$. Decreased sympathetic activity to the smooth muscle of blood vessels will cause relaxation and vasodilation so that blood pressure will drop ${ }^{[11]}$. Music provides a positive stimulus to the limbic system in the brain ${ }^{[12]}$. The limbic system is associated with emotional behavior (anger and fear), thereby it reduces the activity of the autonomic nervous system, creating a relaxed feeling. A relaxed feeling will stimulate the production of Nitric Oxide (NO) hormone ${ }^{[13]}$. NO hormone is synthesized by vascular endothelial cells from the arginine amino acid which is frequently found in plasma. The effect of NO on the cardiovascular system is as a vasodilator agent, so it can reduce blood pressure $^{[14]}$. The therapy of music and humor combination (SIKKOMO) is able to synergize and strengthen blood pressure reduction.

Table 3 shows that there is significant difference on the systolic blood pressure of experimental group and control group $(\mathrm{p}<0.05)$, while the diastolic blood pressure on the experimental group and control group is not significantly different $(p>0.05)$. An individual who grows older and enters the elderly period ( $>60$ years) will experience peripheral resistance occur due to narrowing of the arteries and arterioles, decreased capillary blood vessel density, and decreased peripheral elasticity. This increases venus return and preload which in turn causes systolic and diastolic dysfunction ${ }^{[15]}$. This thing allows no significant differences between the two groups. Other possibilities include basic data from the two groups of respondents showing varied blood pressure and all respondents aged> 60 years (elderly).groups was not significantly different ( $p>0.05)$. A person who experiences aging and goes into the elderly (> 60 years) peripheral resistance will occur due to narrowing of the arteries and arterioles, decreased capillary blood vessel density, and also a decrease in peripheral elasticity. This increases venus return and preload which in turn causes systolic and diastolic dysfunction ${ }^{[15]}$. This allows no significant differences between the two groups. Other possibilities include basic data from the two groups of respondents which shows various blood pressure and similar age range of all respondents that is over 60 years old.

An individual who prays fervently will have a positive effect on the physiology of the body that is received to the brainstem. After formatted with the brain language, 
pray is transmitted to one part of the cerebrum, the thalamus. Then the thalamus transmits the hippocampal impulse (a vital memory center coordinating everything absorbed by the senses) to secrete Gama Amino Batiric Acid (GABA) which acts as a controller of emotional responses, and block acetylcholine, serotonin and other neurotransmitters that produce cortisol secretion that leads to the occurrence of homeostasis and able to reduce blood pressure ${ }^{[7]}$. Table 3 shows that the group receiving SIKKOMODO therapy and the one which only receives a combination of two therapies, music and humor, have a significant difference in their systolic blood

pressure. The combination of three types of appropriate therapy can have a strengthening effect to lower the blood pressure rather than just combining two types of complementary therapies in reducing blood pressure.

Music can influence several physiological functions such as respiration, heart rate and blood pressure ${ }^{[8]}$. It can also reduce myocardial oxygen demand and improve sleep quality. A relaxed condition will stabilize the metabolic rate and the body's oxygen demand, so that vital signs such as pulse, respiratory rate, and blood pressure are within normal limits ${ }^{[16]}$. In addition, it can decrease the adrenaline andnonadrenaline secretion. The effect of adrenaline decrease on the cardiovascular system is a decrease on the heart rate and blood pressure, while non-adrenaline decrease causes a decrease in blood pressure ${ }^{[17]}$. Music stimulates the central nervous system directly and will affect the subject's cognitive and physiological situation. Besides, it affects the expression of opiate receptors, morphine- 6 glucuronate, and interleukin- 6 levels on healthy volunteers. The effect can be moderated by nitric oxide ${ }^{[18]}$. Music can improve emotional responses, aggressive or receptive conditions, and stimulate the limbic system. The harmony structure, interval quality, and tone color will be recognized by the non-dominant hemisphere (mostly in the right hemisphere) temporarily and permanently. Short-term melodies in music, such as volume variations, tone counts, and lyrics are recognized by the dominant brain hemisphere ${ }^{[19]}$.

When someone laughs, the release of endorphins hormone occurs. This hormone is believed to help fixing the condition of blood vessels. The release of this hormone in large quantities also occurs after a person exercises. In addition, laughing will stimulate the release of nitric oxide, which is a gas that can relax the endothelium (one part of the blood vessels). In one study, it is found that laughter can improve the immune system up to $40 \%$. Therefore, health professionals should consider humor as a therapy ${ }^{[5]}$.

People who laugh a lot will feel more free to breathe, because laughter speeds up the release of saturated air from the body which is immediately replaced by fresh air. This alteration will enrich the blood with oxygen and clean the respiratory parts or organs. Strong breathing will also train the heart muscle, improve blood circulation, accelerate the flow of oxygen, and nutrient contraction of the heart muscle will be better trained in term of rhythmic rhythms of the brain. As a result, the bloodstream is getting better. Blood within the vessels will transport oxygen and nutrients faster to meet their needs throughout the body and improve the nutritional function of the body circulation. During laughter, antibodies and white blood cells actively prevent infection, while hormones can improve alertness and memory function ${ }^{[5]}$.

People who often laughs or gets relaxed will experience the release of endorphins and enkephalin that function as endogenous opiates. Endorphin provides relaxation. A relaxed condition will stabilize the metabolic rate and the body's oxygen demand, 
so that vital signs such as heart rate, respiratory frequency, and blood pressure are within normal limits ${ }^{[16]}$. A relaxed feeling can reduce the secretion of adrenaline and non-adrenaline. The effects of adrenaline on the cardiovascular system include an increase on heart rate and blood pressure, while non-adrenaline causes an increase in blood pressure ${ }^{[17]}$.

Praying is a form of physical, psychological, and religious compassion so that all elements of the body become more relaxed. Someone who prays and does dhikr by mentioning the name of Allah, he actually invigorates the qualities and names of Allah that have extraordinary power inside himself. As a consequence, he has the spiritual power that makes him feel peaceful and balanced. A peaceful soul can normalize the organs of the body, arouse the balance and positive thoughts, and affect healing. The prayer can be done through the servitude process by uttering the name of Allah repeatedly. Then it can be continued by confessing that all power belong to Allah only by saying "La haullawalaquwata ill billah" along with appreciation. Dhikr can also normalize the work of the sympathetic nerves and the heart rate ${ }^{[20]}$. While in diastolic blood pressure, it does not show a significant difference because elderly has experienced vascular dysfunction which results in diastolic dysfunction ${ }^{[15]}$.

\section{Conclusion}

The average of respondent's blood pressure is categorized as moderate hypertension (systolic blood pressure is $160-179 \mathrm{mmHg}$ ). There is a difference in blood pressure before and after SIKKOMODO therapy.There is a difference in blood pressure before and after music and humor combination therapy.There is a significant difference in systolic blood pressure between the treatment and the control groups, however there is no significant difference in diastolic blood pressure between the two groups.

\section{Suggestion}

SIKKOMODO therapy can be used as part of nursing intervention in attempt to reduce blood pressure and keep the heart rate in normal conditions in nursing services.It is used as a recommendation for curriculum development for complementary therapy subject, especially SIKKOMODO therapy for nursing education institutions.For further research, it is necessary to have a combination with other therapies lower blood pressure to the normal limits.

\section{Acknowledgments}

We greatly acknowledge to Rector, Head of LPPM JenderalSoedirman University, all patient and all parties who have helped in this research.

\section{References}

[1] Smeltzer, C. Suzanne, Buku Ajar MedikalBedah Brunner \&Suddarth / editor, Suzanne C. Smeltzer, Brenda G. Bare ; alihbahasa, AgungWaluyo....[et al] ; editor edisibahasa Indonesia, Monica Ester. - Ed. 8. Vol 2 - Jakarta: EGC (2008) 
[2] S. Awaludin, I. Purnawan,, G.N. Alivian, Pengaruh terapi humor untuk menurunkan nyeri kepala akibat hipertensi di Kelurahan Mersi Purwokerto.. Kumpulan Abstrak Semnas . LPPM Universitas Jenderal Soedirman (2016)

[3] WHO, Report of hypertensions. WHO/CDS/RBM/2001.35. Geneva 28-30 March 2009

[4] B. Kozier, Fundamental of nursing : Concept, process and practice, $7^{\text {th }}$ edition. New Jersey: Pearson Education Inc. (2014)

[5] L. Keegan, Delmar Thomson Learning (2001)

[6] A.F. Elkaysi, Pengobatan doa-zikir dan ruqyah. Jakarta :MutiaraMedia (2012)

[7] M. Sholeh, Agama sebagai terapi telaah menuju kedokter anholistik. Yogyakarta :PustakaPelajar (2005)

[8] E. Geer, A.C. Vink, J.M. Schols, J.P. Slaets, International Phychogeriatrics. 21, 86-93 (2009)

[9] S. Ismail, C. Kritpracha, P. Thaniwattananan, The effects of music intervension on aniety reduction in patients with ventilator support. Makalah dipresentasikan pada Java International Nursing Conference tanggal 2-3 Oktober, Semarang (2010).

[10] J. M. White, Critical Care Nurse Clinical North America. 12 (2), 219-225 (2000)

[11] S. Oparil, A.M. Zaman, D.A. Calhoun, Ann Intern Med. 139, 761-776 (2003)

[12] Hidayat. (2006). Terapi musik teori dan aplikasi. Cetakan pertama. Yogyakarta: Galang Press (2006)

[13] Champbell, Efek Mozart: Memanfaatkan kekuatan musik untuk mempertajam pikiran,meningkatkan kreativitas dan menyehatkan tubuh. Jakarta: Gramedia Pustaka Utama (2001)

[14] L.P. Hooi, The effect of music intervention on anxiety and pain in female surgical patients.Unpublished Dissertation, Prince of Songkla University, Hatyai (2007)

[15] E.L. Schiffrin, Hypertension 19 (2 Suppl): II1-9. PMID 1735561 (2000)

[16] A.G. Perry, and P.A. Potter, Konsep, proses danpraktik.(4,vol 2. St.Louis: Mosby, 2005)

[17] N. Ulrica, Associations of operating room nurses (AORN) Journals. 83 (4); 780 (2008)

[18] Kemper, J. Kathi, Danhauer, C. Suzzane, C. Journal of Clinical Nursing, 6 (5), $341-346(2005)$

[19] E.T. Chang, H.L. Lai, P.W. Chen, Y.M. Hsieh, L.H. Lee, International Journal of Nursing Studies. 928 (2018)

[20] N. Yanti, Perbandingan efektifitas terapi zikir dengan relaksasi Benson terhadap kadar glukosa darah pasien Diabtes Melitus di Sumatera Barat. Universitas Indonesia (2012) 